\title{
EKSTRAK TEH HIJAU MENINGKATKAN EKSPRESI ER- $\alpha$ PADA ENDOMETRIUM DAN TUBA FALOPI TIKUS BETINA (Rattus norvegicus) YANG DIPAPAR SIPERMETRIN
}

\author{
GREEN TEA EXTRACT INCREASE ER- $\alpha$ EXPRESSION ON ENDOMETRIUM AND \\ FALLOPIAN TUBE OF FEMALE RAT (Rattus norvegicus) EXPOSED BY \\ CYPERMETHRIN \\ $\underline{\text { Ririn Handayani }^{1)} \text {, Lia Sawitri }}{ }^{2)}$, Sri Winarsih ${ }^{3)}$, Retty Ratnawati ${ }^{4}$, Eviana Norahmawati ${ }^{5}$, \\ Kenty Wantri Anita ${ }^{6}$ \\ ${ }^{1), 2)}$ Magister Kebidanan, Kedokteran, Universitas Brawijaya \\ ${ }^{3)}$ Farmasi, Kedokteran, Universitas Brawijaya \\ ${ }^{4)}$ Keperawatan, Kedokteran, Universitas Brawijaya \\ ${ }^{5), 6)}$ Departemen Patologi Anatomi RSSA \\ Email : zahraaina12@gmail.com
}

\begin{abstract}
ABSTRAK
Infertilitas banyak terjadi pada wanita karena gangguan sistem reproduksi yang bisa disebabkan oleh pestisida (sipermentrin). Paparan sipermetrin dapat memberi dampak pada otak yang menyebabkan kerusakan hipotalamus melalui proses stres oksidatif. Kemudian dapat mempengaruhi sekresi dari GnRH, LH dan FSH pada proses umpan balik hormon endogen. Sehingga akan mempengaruhi proses folikulogenesis dan menghasilkan estrogen sedikit. Estrogen ini akan menstimulasi pertumbuhan sel jika berikatan dengan reseptornya (ER- $\alpha)$. Teh hijau dengan kandungan antioksidan yang tinggi mampu menghambat radikal bebas. Jenis flavonol dari teh hijau umumnya dikenal sebagai catechin yaitu EGCG. EGCG bekerja sama dengan antioksidan endogen untuk melindungi tubuh dari reaksi stres oksidatif. Tujuan dari penelitian ini untuk membuktikan pemberian ekstrak teh hijau dapat meningkatkan ekspresi ER- $\alpha$ pada endometrium dan tuba falopi tikus betina yang dipapar sipermetrin. Penelitian ini merupakan penelitian eksperimental. Proses ekstraksi dengan metode maserasi. Pemeriksaan ekpresi ER- $\alpha$ dengan metode imunohistokimia (IHK). Data dianalisis menggunakan uji Rank Spearman. Hasil uji statistik didapatkan nilai korelasi 0,776 untuk ekspresi ER- $\alpha$ pada endometrium dan 0,718 untuk ekspresi ER- $\alpha$ pada tuba falopi. Berdasarkan hasil penelitian dapat disimpulkan bahwa ada hubungan positif searah dan cukup kuat antara pemberian ekstrak teh hijau dengan ekspresi ER- $\alpha$ pada endometrium dan tuba falopi. Semakin tinggi dosis yang diberikan semakin tinggi ekspresi yang dihasilkan.
\end{abstract}

Kata kunci : Teh hijau, sipermetrin, Ekspresi ER $\alpha$

\section{ABSTRACT}

Infertility occurs mostly in women due to reproductive system disorders that can be caused by pesticides (cypermethrine). Exposure to cypermethrine can have an effect on the brain that causes hypothalamic damage through the process of oxidative stress. Then it can affect the secretion of GnRH, LH and FSH on endogenous hormone feedback process. So that will affect the process of folikulogenesis and produce a little estrogen. This estrogen will stimulate cell growth if it binds to its receptor $(E R-\alpha)$. Green tea with high antioxidant content can inhibit free radicals. This type of flavonol from green tea is commonly known as catechin EGCG. EGCG works with endogenous antioxidants to protect the body from oxidative stress reactions. The purpose of this study to prove the provision of green tea extract can increase the expression of ER- $\alpha$ in endometrium and fallopian tubes of female mice exposed to cypermethrine. This research is an experimental research. Extraction process by maseration method. Examination of ER- $\alpha$ expression by immunohistochemical method (IHC). Analyzed using Rank Spearman test. Statistical test results obtained correlation value 0.776 for ER- $\alpha$ expression in endometrium and 0.718 for ER- $\alpha$ expression in fallopian tubes. Based on the results of this study it can be concluded that there is a positive and unequivocal positive relationship between green tea extract with ER- $\alpha$ expression on endometrium and fallopian tubes. The higher the dose given the higher the resulting expression.

Kata kunci : Green Tea, Cypermethrin, ER- $\alpha$ Expression

\section{PENDAHULUAN}

dari $\begin{array}{rrr}\text { Infertilitas } & \text { merupakan kelainan } \\ \text { sistem } & \text { reproduksi } & \text { yang }\end{array}$ menyebabkan pasangan suami - istri mengalami kegagalan kehamilan setelah melakukan hubungan secara rutin dan tanpa alat kontrasepsi setelah 12 bulan atau lebih (Prawiroharjo, 2008). Pasangan infetil tingkat dunia mencapai $10-15 \%$, dari jumlah tersebut $90 \%$ diketahui penyebabnya, sekitar 
$40 \%$ diantaranya berasal dari faktor wanita (Hadibroto, 2013). Pasangan infertil di Indonesia tahun 2013 sebanyak 50 juta atau $15-20 \%$ dari seluruh pasangan yang ada (Riskesdas, 2013).

Infertilitas pada wanita dapat disebabkan adanya kelainan pada uterus $(33 \%)$, tuba $(8,6 \%)$ (Oktarina, 2014). Salah satu faktor risiko terjadinya infertilitas antara lain pengaruh paparan lingkungan atau pekerjaan meliputi panas, radiasi, dan pestisida (Hestiantoro, 2013). Jenis pestisida yang digunakan petani adalah insektisida golongan piretiroid yaitu sipermetrin (Ujiantari, 2016).

Paparan pestisida ini dapat menimbulkan adanya residu pada produk tersebut yang dapat mengakibatkan gangguan kesehatan pada manusia. Kandungan bahan kimia dari pestisida tersebut dapat meracuni sel-sel tubuh manusia karena kemampuannya menumpuk (akumulasi) dalam lemak (Amir. 2014). Pada mamalia Cypermethrin dapat terakumulasi dalam lemak tubuh, kulit, hati, ginjal, kelenjar adrenal, ovarium, paru-paru, darah dan jantung. Namun target utama dari sipermetrin ini adalah sistem saraf pusat. Selain neuron, organ target lain dari sipermetrin adalah organ reproduksi (Wang, 2009).

Loekman et al. (2010), menyatakan adanya residu pestisida pada dalam sayuran kubis yaitu residu cypermethrin sebanyak 2,08 mg/kg. Di daerah Lamongan pada produk jambal roti yang terbuat dari ikan manyung juga terdeteksi adanya residu cypermethrin yaitu sebesar 2,124 $\mathrm{mg} / \mathrm{kg}$. Kadar residu ini jauh diatas ambang batas maksimum residu (BMR) yang diperbolehkan sesuai dengan SNI dan CAC (Amir, 2014). Menurut SNI 7313 (2008) ambang batas normal residu pestisida adalah 0,05 mg/kg (BSN, 2008).

Efek paparan pestisida pada wanita dapat mengganggu sistem reproduksi (Bretveld, 2006). Pada penelitian yang telah dilakukan oleh Respatiningrum (2016), menjelaskan bahwa cypermethrin secara signifikan dapat menginduksi apoptosis dan penurunan ketebalan endometrium.
Cypermethrin dapat mempengaruhi ketebalan endometrium dengan cara mengganggu neurotransmisi dan regulasi endokrin yang mengarah pada perubahan fisiologis organ reproduksi (Gill et al. 2011).

Cypermethrin terlibat dalam stres oksidatif dengan memediasi neurotoksisitas (Singh et al, 2012). Beberapa efek yang ditimbulkan oleh oksidatif stres terhadap siklus reproduksi adalah pematangan oosit yang terganggu, steroidogenesis ovarium, ovulasi, implantasi, pembentukan blastokista dan pemeliharaan luteal pada kehamilan. Regenerasi dari siklus endometrium dapat terganggu karena estrogen dalam tubuh rendah (Agarwal, 2005).

Estrogen diproduksi oleh ovarium selama maturasi folikel dan akan menstimulasi proliferasi kelenjar pada bagian dalam atau endometrium (Greeinstein, 2006). Estrogen dapat berfungsi jika berikatan dengan reseptornya (Speroff, 2005). Gen reseptor yang dikenal sebagai reseptor dari hormon estrogen adalah RE- $\alpha$ dan RE- $\beta$ (Gruber et al., 2002).

Untuk berikatan dengan reseptornya, estrogen harus menembus permukaan sel dan masuk kedalam sel (sitoplasma) kemudian berikatan dengan reseptor estrogen di sitoplasma dan membentuk ikatan hormon reseptor pada Estrogen Responsive Element yang kemudian bergerak menuju inti sel untuk berikatan dengan DNA (Speroff and Fritz, 2005). Apabila hormon estrogen tidak ada, maka reseptor estrogen akan bersifat inaktif dan berada di dalam inti sel target dan berikatan dengan heat shock protein. Hormon estrogen yang masuk ke dalam sel target akan berikatan dengan reseptor estrogen yang berada di inti dan menyebabkan reseptor estrogen menjadi aktif (McDonnel \& Norris, 2002).

Pada penelitian ini menggunakan ekstrak teh hijau. Dimana teh hijau memiliki kandungan antioksidan yang tinggi. Sebagian besar polifenol yang terkandung didalam teh hijau adalah flavonol yang umumnya dikenal sebagai catechin. Jenis cathecin yang paling utama pada teh hijau ini adalah EGCG. EGCG ini dapat melindungi 
tubuh dari reaksi stres oksidatif bekerja sama dengan vitamin antioksidan dan enzim (SOD, katalase) sebagai pertahanan antioksidan. (Chacko, 2010)

Dari uraian diatas peneliti ingin membuktikan bahwa pemberian ekstrak teh hijau dapat meningkatkan ekspresi ER- $\alpha$ pada endometrium dan tuba falopi tikus betina galur wistar (Rattus norvegicus) yang dipapar sipermetrin.

\section{METODE PENELITIAN}

Penelitian ini merupakan penelitian eksperimental dengan post test only with control group design. Sampel penelitian menggunakan 25 ekor tikus betina dibagi kedalam lima kelompok. Kelompok KN (tanpa perlakuan), kelompok KP (sipermetrin $20 \mathrm{mg} / \mathrm{kg} \mathrm{BB}$ ), PI (sipermetrin 20 $\mathrm{mg} / \mathrm{kg} \mathrm{BB}+$ ekstrak teh hijau $7 \mathrm{mg} / \mathrm{kg}$ BB), PII (sipermetrin $20 \mathrm{mg} / \mathrm{kg} \mathrm{BB}+$ ekstrak teh hijau $14 \mathrm{mg} / \mathrm{kg} \mathrm{BB}$ ), dan PIII (sipermetrin $20 \mathrm{mg} / \mathrm{kg} \quad \mathrm{BB}+$ ekstrak teh hijau $28 \mathrm{mg} / \mathrm{kg}$ BB). Pemeliharaan tikus dilakukan di Laboratorium Farmakologi FKUB. Pemaparan dilakukan secara oral per sonde selama 28 hari. Proses pembedahan dilakukan setelah 28 hari pemaparan dan tikus berada pada fase

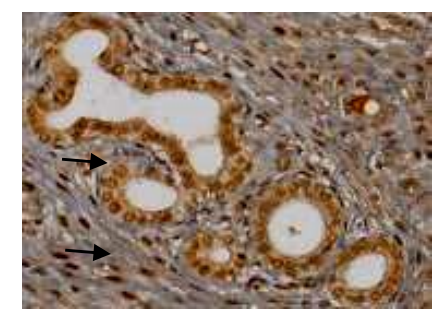

$\mathrm{KN}$

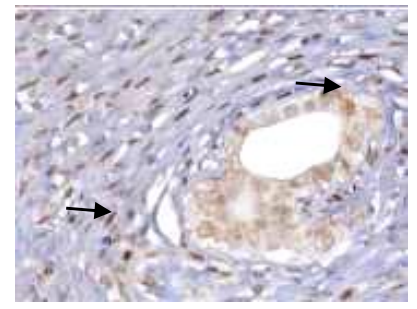

$\mathrm{KP}$

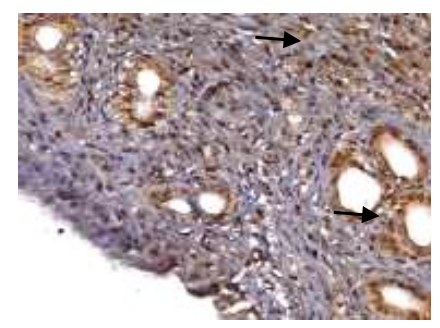

P2

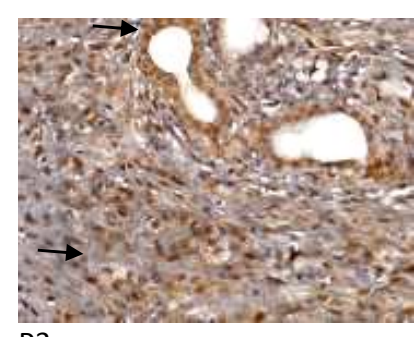

P3 proestrus. Pemeriksaan ekpresi RE- $\alpha$ menggunakan metode imunohistokimia (IHK). Pemeriksaan IHK dilakukan di Laboratorium Patologi Anatomi FKUB. Data dianalisis menggunakan uji korelasi Rank Spearman.

Proses ekstraksi teh hijau dilakukan di Laboratorium Farmakologi FKUB dengan metode maserasi. Bahan yang digunakan sebanyak 100 gr teh hijau kering. Larutan sipermetrin didapat dari toko pertanian. Penelitian ini dilakukan selama 2 bulan (januari - februari 2018).

\section{HASIL DAN PEMBAHASAN}

\section{Ekspresi ER $\alpha$ Endometrium}

Perhitungan ekspresi ER $\alpha$ dilakukan menggunakan mikroskop Olympus BX51, pengamatan dilakukan pada pembesaran $400 x$ pada 10 lapang pandang. Hasil pengamatan dihitung menggunakan software ImmunoRatio. Ekspresi ER $\alpha$ ditunjukkan oleh inti yang berwarna coklat seperti pada gambar dibawah ini:

\section{Gambar 1 Ekspresi ER $\boldsymbol{\alpha}$ Endometrium}

Keterangan : Ekspresi ER $\alpha$ endometrium tikus dengan metode IHK dengan pembesaran 400x. Warna coklat yang ditunjukkan anak panah menunjukkan adanya ekspresi ER $\alpha$ pada inti sel. KN tanpa perlakuan, memiliki ekspresi ER $\alpha$ yang paling tinggi dibandingkan dengan KP, P1, P2 dan P3. P3 diberi cypermethrin $20 \mathrm{mg} / \mathrm{kg}$ BB dan ekstrak teh hijau $28 \mathrm{mg} / \mathrm{kg}$ BB per oral selama 28 hari, memiliki ekspresi ER $\alpha$ yang paling tinggi dibandingkan dengan $\mathrm{P} 1$ dan $\mathrm{P} 2$, hampir sama dengan $\mathrm{KN}$. 


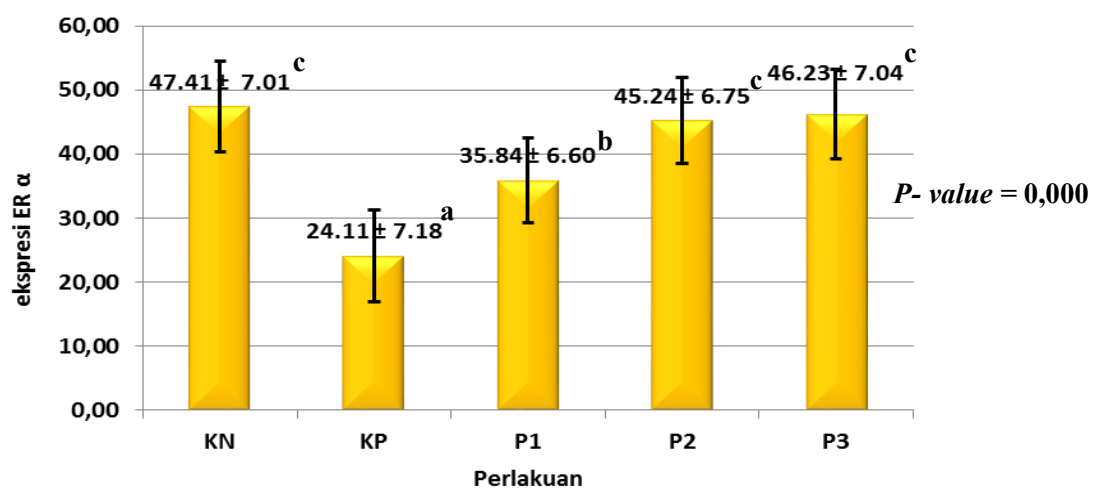

\section{Gambar 2 Rata - rata Jumlah Ekspresi ER $\alpha$ pada Endometrium}

Keterangan : KN tanpa perlakuan, memiliki ekspresi ER $\alpha$ yang paling tinggi berbeda signifikan dengan KP yang diberi cypermethrin $20 \mathrm{mg} / \mathrm{kg}$ BB per oral selama 28 hari. P3 diberi cypermethrin 20 $\mathrm{mg} / \mathrm{kg}$ BB dan ekstrak teh hijau $28 \mathrm{mg} / \mathrm{kg}$ BB per oral selama 28 hari, memiliki ekspresi ER $\alpha$ yang paling tinggi dibandingkan dengan $\mathrm{P} 1$ dan $\mathrm{P} 2$, hampir sama dengan $\mathrm{KN}$

Pada kelompok KN memiliki rata - rata jumlah ekspresi ER $\alpha$ yang paling tinggi berbeda signifikan dengan KP dan P1, namun tidak berbeda signifikan dengan P2 dan P3. Sedangkan kelompok KP memiliki rata - rata jumlah ekspresi ER- $\alpha$ yang paling rendah berbeda signifikan dengan kelompok KN, P1, P2 dan P3. Pada kelompok paparan, P3 memiliki rata - rata jumlah ekspresi ER $\alpha$ yang paling tinggi berbeda signifikan dengan KP dan P1.

Hasil uji korelasi dengan menggunakan Rank Spearman

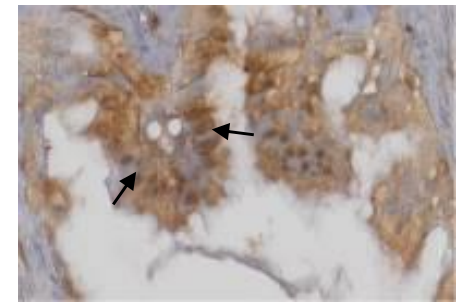

KN

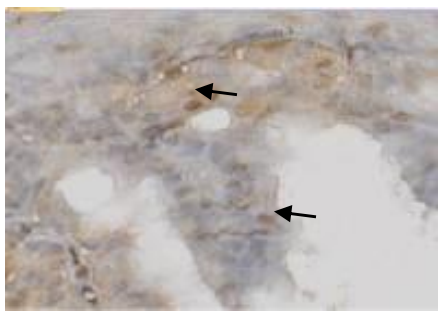

KP

menunjukkan koefisien korelasi sebesar 0,776 untuk ekspresi ER- $\alpha$ pada endometrium artinya ada hubungan positif searah dan cukup kuat antara pemberian ekstrak teh hijau dengan peningkatan ekspresi ER- $\alpha$ pada endometrium.

\section{Ekspresi ER $\alpha$ Tuba Falopi}

Ekspresi ER- $\alpha$ ditunjukkan oleh inti sel yang berwarna coklat. Pengamatan dilakukan dengan menggunakan mikroskop pada pembesaran 1000X 10 lapang pandang
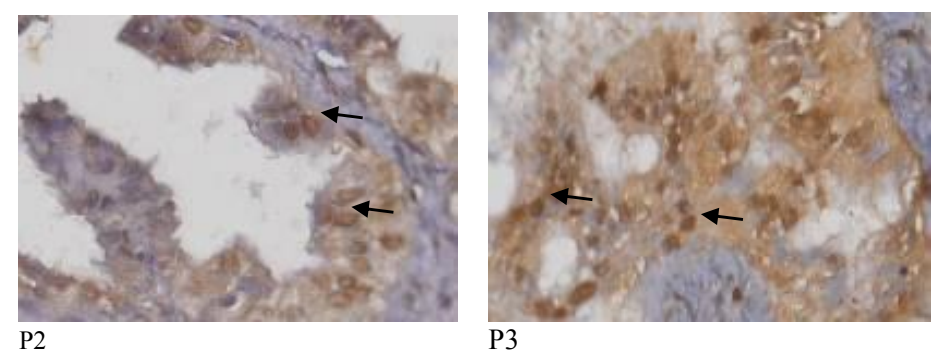

P3

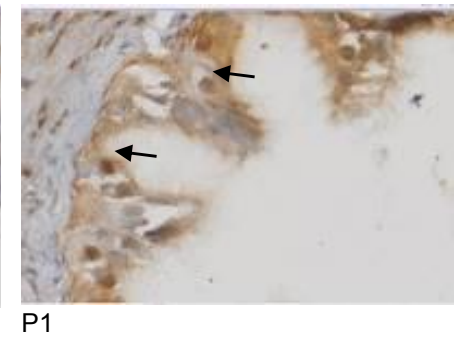

Gambar 3. Ekspresi ER $\alpha$ Tuba Falopi

Pewarnaan dengan metode IHK, pengamatan pada pembesaran 1000x. Tanda panah menunjukkan inti sel yang mengekspresikan ER $\alpha$ berwarna coklat. Ekspresi ER $\alpha$ pada P3 menunujukkan jumlah ekspresi ER $\alpha$ paling banyak, sedangkan P1 menunjukkan ekspresi ER $\alpha$ paling sedikit diikuti oleh P2 dan KP, namun tidak berbeda secara signifikan. 
p-value $=0,003$

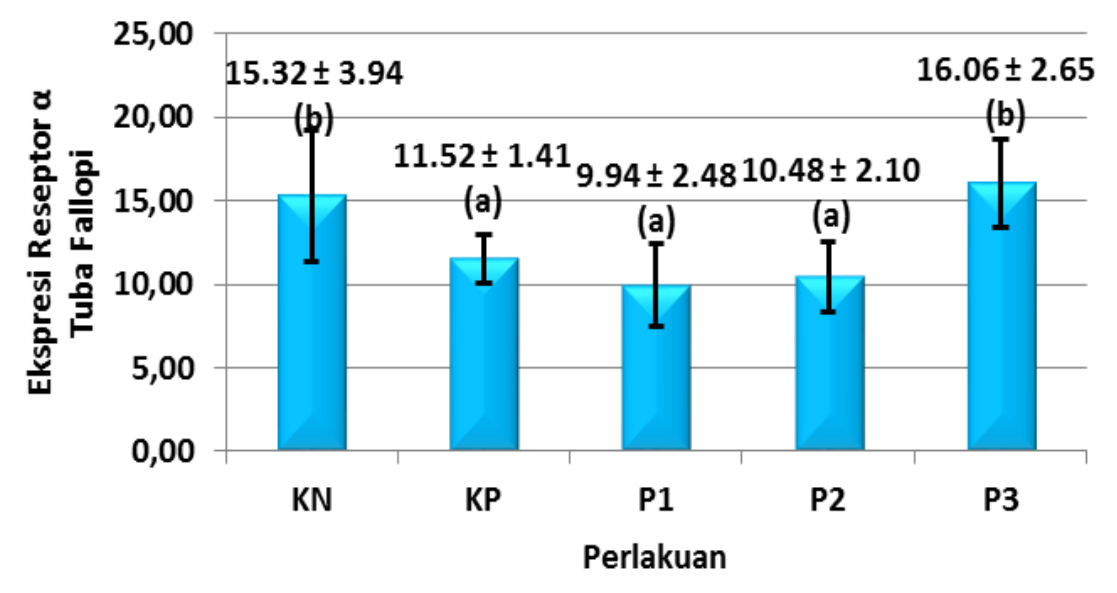

Gambar 4. Histogram Rerata ekspresi ER $\alpha$ pada tuba fallopi

Keterangan: $\mathrm{KN}$ : tidak mendapat sipermetrin dan tidak mendapat ekstrak teh hijau $\mathrm{KP}$ : sipermetrin $20 \mathrm{mg} / \mathrm{KgBB} / \mathrm{hari}$

P1 : sipermetrin $20 \mathrm{mg} / \mathrm{KgBB} /$ hari dan ekstrak teh hijau $7 \mathrm{mg} / \mathrm{KgBB} /$ hari

P2 : sipermetrin $20 \mathrm{mg} / \mathrm{KgBB} /$ hari dan ekstrak teh hijau $14 \mathrm{mg} / \mathrm{KgBB} / \mathrm{hari}$

P3 : sipermetrin $20 \mathrm{mg} / \mathrm{KgBB} / \mathrm{hari}$ dan ekstrak teh hijau $28 \mathrm{mg} / \mathrm{KgBB} / \mathrm{hari}$

Gambar 3 dan 4 menunjukkan bahwa kelompok perlakuan 3 (sipermetrin $20 \mathrm{mg} / \mathrm{KgBB} /$ hari dan ekstrak teh hijau $28 \mathrm{mg} / \mathrm{KgBB} /$ hari) memiliki ekspresi reseptor $\alpha$ yang paling banyak dan berbeda signifikan kelompok perlakuan kontrol positif, kelompok perlakuan 1 (sipermetrin 20 $\mathrm{mg} / \mathrm{KgBB} /$ hari dan ekstrak teh hijau $7 \mathrm{mg} / \mathrm{KgBB} /$ hari), dan kelompok perlakuan 2 (sipermetrin 20 $\mathrm{mg} / \mathrm{KgBB} /$ hari dan ekstrak teh hijau $14 \mathrm{mg} / \mathrm{KgBB} /$ hari), namun berbeda tidak signifikan dengan kelompok kontrol negatif (KN).

Hasil uji korelasi dengan menggunakan Rank Spearman menunjukkan koefisien korelasi sebesar 0,718 untuk ER- $\alpha$ pada tuba falopi, artinya ada hubungan positif searah dan cukup kuat antara pemberian ekstrak teh hijau dengan peningkatan ekspresi ER- $\alpha$ tuba falopi. Bretveld (2006), menyatakan bahwa cypermethrin dapat mengganggu fungsi hormon dari sistem reproduksi wanita, khususnya pada siklus ovarium. Penelitian serupa juga telah dilakukan oleh Al-Hamdani (2017) tentang efek cypermetrin yang telah dilaporkan memberikan efek buruk pada fungsi ovarium, tingkat kesuburan dan pubertas. Pengaruh paparan sipermetrin secara oral dapat berdampak pada organ otak dan organ reproduksi. Kosentrasi sipermetrin yang tinggi pada otak menyebabkan peningkatan ROS, hingga apoptosis sel-sel otak. Apoptosis sel otak dapat mengganggu aktivitas hipotalamus dalam memberikan sinyal untuk sekresi hormon yaitu sekresi dari GnRH, LH dan FSH pada proses umpan balik dari hormon endogen. Rendahnya kadar LH dan FSH akan mempengaruhi proses folikulogenesis sehingga estrogen yang dihasilkan sedikit (Bretveld et al., 2006). Stimulasi

estrogen meningkatkan ukuran dan jumlah sel di endometrium dan tuba, yang disertai dengan tahapan pembentukan reseptor estrogen yang spesifik dan proses sintesa protein (Mylonas et al., 2005). Untuk berikatan dengan reseptornya, estrogen harus menembus permukaan sel dan masuk kedalam sel (sitoplasma) kemudian berikatan dengan reseptor estrogen di sitoplasma dan membentuk ikatan hormon reseptor pada Estrogen Responsive Element yang kemudian bergerak menuju inti sel untuk berikatan dengan DNA (Speroff and Fritz, 2005). Apabila hormon estrogen tidak ada, maka reseptor estrogen akan bersifat 
inaktif dan berada di dalam inti sel target dan berikatan dengan heat shock protein. Hormon estrogen yang masuk ke dalam sel target akan berikatan dengan reseptor estrogen yang berada di inti dan menyebabkan reseptor estrogen menjadi aktif (McDonnel \& Norris, 2002).

Ekstrak teh hijau memiliki kandungan polifenol yang tinggi dan memiliki efek perlindungan terhadap ROS dan patologi lainnya. Polifenol dari teh hijau mampu menghambat superoksida radikal (O2-), hidroksil radikal $(\mathrm{OH})$ dan peroksill radikal (ROO) (Wu Weanbiao, 2013). Teh hijau berperan sebagai antioksidan yang sangat baik untuk aktivitas biologis, seperti penghambatan enzim oksidatif, penghambatan faktor transkripsi pada kanker, membersihkan oksigen reaktif dan reduksi logam chelation (Rashidinejad, 2016). Peran antioksidan secara umum adalah menstimulasi sel theca interstisil, mengontrol pertumbuhan folikel dan atresia folikel, merangsang steroidogenesis serta memberikan rangsangan mekanis pada folikel di ovarium. Folikel yang berkembang akan menstimulasi pertumbuhan sel epitel (Ruder, 2008).

Pada penelitian ini pemberian ekstrak teh hijau mampu meningkatkan ekspresi ER $\alpha$ pada endometrium dan tuba falopi tikus betina (Rattus norvegicus) yang dipapar cypermethrin. Hal ini sesuai dengan penelitian yang telah dilakukan oleh Suherlin (2017) yang menyatakan bahwa pemberian ekstrak teh hijau dapat meningkatkan jumlah sel epitel sekretorik dan reseptor estrogen- $\alpha$ tuba falopi pada tikus yang dipapar MSG. Katekin dalam teh hijau berperan besar menghambat superoksida, hidrogen peroksida, radikal hidroksil, dan asam nitrat yang berasal dari berbagai bahan kimia yang masuk ke dalam tubuh. Katekin juga menyebabkan adanya struktur katekol yang melekat pada logam dan menghambat pembentukan radikal bebas, serta menyebabkan besarnya perbedaan tingkat serum LH dan FSH antara eksperimental dan kelompok kontrol pada tikus betina yang dipapar Cadmium Chloride dapat menyebabkan stress oksidatif (Mahmood, 2015)

Teh hijau mempunyai aktivitas antioksidan yang sangat kuat dengan kandungan polifenol yang berperan menangkal radikal bebas dan sebagai co-faktor enzim antioksidan di dalam tubuh seperti, super okside dismutase (SOD), Catalase (CAT), glutathione peroxide (GPx). Ekstrak teh hijau dapat menghambat radikal bebas yang terjadi pada hipotalamus akibat paparan sipermetrin, sehingga hipotalamus dapat berfungsi secara normal dalam mensekresi GnRH, sehingga jumlah estrogen yang dihasikan semakin banyak dan yang berikatan dengan reseptornya semakin meningkat.

Teh hijau mengandung dua aktif komponen yaitu polifenol katekin yang menghambat aktivitas enzimatik dari catechol-o-methyltransferase, dan kafein yang menghambat dekomposisi yang disebabkan oleh induksi phosphodiesterase yang menyebabkan norepinefrin akan dirilis. Norepinefrin menyebabkan sekresi pulsatil GnRH melalui hipofisis vena portal. GnRH mengikat reseptornya pada sel gonadotropik yang terletak di anterior hipofisis shingga meningkatkan kadar kalsium (dengan aktivasi fosfolipase C, D dan A), yang akhirnya dapat mempengaruhi sekresi hormon steroid (Mahmood, et.al. 2015).

\section{SIMPULAN}

Pemberian ekstrak teh hijau meningkatan ekspresi ER- $\alpha$ pada endometrium dan tuba falopi. KN (tanpa perlakuan) memiliki ekspresi ER- $\alpha$ yang paling tinggi dibandingkan dengan KP, P1, P2 dan P3. P3 diberi cypermethrin $20 \mathrm{mg} / \mathrm{kg} \quad \mathrm{BB}$ dan ekstrak teh hijau $28 \mathrm{mg} / \mathrm{kg}$ BB per oral selama 28 hari, memiliki ekspresi ER$\alpha$ yang paling tinggi dibandingkan dengan $\mathrm{P} 1$ dan $\mathrm{P} 2$, hampir sama dengan $\mathrm{KN}$.

Hasil penelitian menunjukkan bahwa ada hubungan positif searah dan cukup kuat antara pemberian ekstrak teh hijau dengan peningkatan ekspresi ER- $\alpha$ tuba falopi. 


\section{DAFTAR PUSTAKA}

Agarwal, A., Gupta, S., Sharma, Rakesh K. 2005. Role of Oxidative Stress in Female Reproduction. Biomed Central. www.rbej.com

Al-Hamdani, Nada M.H; Yajurvedi. H.N. 2017. Effect of Cypermethrin on the Ovarian Activity and Its Impact on Fertility and Pubertal Onset of Offspring

Amir, N. 2014. Keamanan Pangan Produk Jambal Roti Ikan Manyung (Arius Thalaainus Ruppell) Yang Terpapar Sipermetrin.

Bretveld, Reini W; Thomas, Cris MG; Scheepers, Paul TJ; Zielhuis, Gerhard A and Roeleveld, Nel. 2006. Pesticide exposure : the hormonal function of the female reproductive system disrupted. Reproductive biology and endocrinology.

Chacko, Sabu M; Thambi, Priya T; Kuttan, Ramadasan and Nishigaki, Ikuo. 2010. Beneficial effects of green tea: A literature review.

https://www.ncbi.nlm.nih.gov/p mc/articles/PMC2855614/

Gill, Shahid A; Rizvi, Farzana; Khan, A. 2011. Toxic Effect of Cypermethrin and Methamidopos on Bovine Corpus Luteal Cells and Progesterone Production. www.ncbi.nlm.nih.gov/pubmed

Greenstein B \& Wood D. 2006. At a Glance: Sistem Endokrin. Jakarta : Erlangga. hal. 66-86

Gruber, J., Tachuguel., Schneberger, C., Hubber, J., 2002. Production and Action of Estrogen. The New England Journal of Medicine. 346 (5): 340-348

Hadibroto, I. (2013). Buku saku patofisiologi. Jakarta: EGC
Hestiantoro, A. 2013. Konsensus Penanganan Infertilitas. Jakarta. www.pogi.or.id

Loekman, V., H. Suyani., E. Munaf, R Zein. 2010. Penentuan Sipermetrin dan Permetrin Sebagai Residu Pestisida dalam Kubis Secara HPLC. Jurnal Kimia Andalas Vol.11 No.1

Mahmood, B., Mokhtar, M., Esfandiar, S., 2015. The Impact of Green Tea (Camellia Sinensis) on the Amount of Gonadotropin Hormones (LH, FSH) in Immature Female Rats Poisoned with Cadmium Chloride. Biomedical \& Pharmacology Journal. 8 (1):265-266

McDonnell, D.P. \& Norris, J.D., 2002. Connections and Regulation of the Human Estrogen Receptor. Mapping Cellular Signaling. 269: 1642-1643

Mylonas, I., Jeschke, U., Shabani, N., Kuhn, C., Krigel, S., Kupka, M.S., Friese, K., 2005. Normal and Maglinant Human Endometrium Express Immunohistochemically Estrogen Receptor Alpha (ER- $\alpha)$, Estrogen Receptor Beta (ER- $\beta)$ and Progestrone Receptor (PR). Anticancer Research.25:16791686

Oktarina A, Abadi A, Bachsin R. 2014. Faktor - Faktor yang Mempengaruhi Infertilitas pada Wanita di Klinik Fertilitas Endokrinologi Reproduksi. MKS, Th. 46, No. 4

Prawirohardjo S. 2008. Infertilitas. In: Hanifa Wiknjosastro ABS, Triatmo Rachimhadi, ed. Ilmu Kandungan. Jakarta: PT Bina Pustaka Sarwono Prawirohardjo : 497.

Rashidinejad, A., Birch, E.J., Everet, D.W., 2016. Antioxidant Activity and Recovery of Green Tea Catechins in Full-Fat Cheese 
Following Gastrointestinal Simulated Digestion. Journal of Food Composition and Analysis.

Respatiningrum. 2016. Pengaruh paparan cypermethrin per oral terhadap indeks apoptosis dan ketebalan endometrium tikus betina (ratus novergicus). Tesis Program Studi Magister Kebidanan Fakultas Kedokteran Universitas Brawijaya Malang.

Riskesdas. (2013). Riset kesehatan dasar. Jakarta: Kementrian Kesehatan RI.

Ruder, E.H., Hartman, T.J., Blumberg, J., Goldman, M.B., 2008. Oxidative Stress and Antioxidant : Exposure and Impact on Female Fertility. Human Reproductive Update. 14 (4): 345-357

Singh, Anand Kumar; Nath Tiwari, Manindra; Om Prakash and Singh, Mahendra Pratap. 2012. A current review of cypermethrin induced neurotoxicity and nigrostriatal dopaminergic neurodegeneration. Current neuropharmacology 10:64-71

Speroff, L., Fritz, M.A. 2005. Female Infertility in : Clinical
Gynecology Endocrinology and Infertility. Seventh Edition, PA : Lippincott Williams and Wilkins. Edisi 6. hal 52-66

Suherlin, I. (2017). Pengaruh Pemberian Ekstrak Teh Hijau Terhadap Jumlah Sel Epitel Sekretorik dan Eksprsi Reseptor Estrogen a Tuba Falopi Tikus Wistar Yang Dipapar Monosodium Glutamat. Repository.ub.ac.id

Ujiantari, Navisa S.O. 2016. Kajian Molecular Docking Insektisida Piretiroid Terhadap Reseptor Hormon Reproduksi (Reseptor Estrogen, Androgen Dan Progesteron. RAKERNAS dan PIT Ikatan Apoteker Indonesia.

Wang, X.Z., Liu, S.S., Sun, Y., Wu, J.Y., Zhou, Y.L., Zhang, J.H. 2009. Beta-cypermethrin Impairs Reproductive Function in Male Mice by Inducing Oxidative Stress. Theriogenology 72(2009) 599-611

Wu Weanbiao, 2013. Green Tea Varieties, Productio and Health Benefits. New York :Nova Biomedical. hal 3-11 